\title{
Effect of chemical fertilization and green manure on the abundance and community structure of ammonia oxidizers in a paddy soil
}

\author{
Yu Fang1, Zhi-Lei Yan', Ji-Chen Chen', Fei Wang', Ming-Kuang Wang1, and Xin-Jian Lin ${ }^{1 *}$
}

\begin{abstract}
Ammonia oxidization is a critical step in the soil $\mathrm{N}$ cycle and can be affected by the fertilization regimes. Chinese milkvetch (Astragalus sinicus L., MV) is a major green manure of rice (Oryza sativa L.) fields in southern China, which is recommended as an important agronomic practice to improve soil fertility. Soil chemical properties, abundance and community structures of ammonia-oxidizing bacteria (AOB) and ammonia-oxidizing archaea (AOA) in a MV-rice rotation field under different fertilization regimes were investigated. The field experiment included six treatments: control, without MV and chemical fertilizer (CK); 100\% chemical fertilizer (NPK); $18000 \mathrm{~kg} \mathrm{MV}^{-1}$ plus $100 \%$ chemical fertilizer

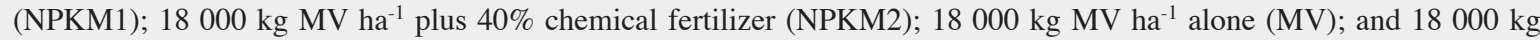
MV ha ${ }^{-1}$ plus $40 \%$ chemical fertilizer plus straw (NPKMS). Results showed that NPKMS treatment could improve the soil fertility greatly although the application of $60 \%$ chemical fertilizer. The abundance of AOB only in the MV treatment had significant difference with the control; AOA were more abundant than AOB in all corresponding treatments. The NPKMS treatment had the highest AOA abundance $\left(1.19 \times 10^{8}\right.$ amoA gene copies $\left.\mathrm{g}^{-1}\right)$ and the lowest abundance was recorded in the CK treatment $\left(3.21 \times 10^{7} \mathrm{amoA}\right.$ gene copies $\left.\mathrm{g}^{-1}\right)$. The abundance of AOA was significantly positively related to total $\mathrm{N}$, available $\mathrm{N}, \mathrm{NH}_{4}{ }^{+}-\mathrm{N}$, and $\mathrm{NO}_{3}{ }^{-}-\mathrm{N}$. The community structure of $\mathrm{AOA}$ exhibited little variation among different fertilization regimes, whereas the community structure of AOB was highly responsive. Phylogenetic analysis showed that all AOB sequences were affiliated with Nitrosospira or Nitrosomonas and all AOA denaturing gradient gel electrophoresis (DGGE) bands belonged to the soil and sediment lineage. These findings could be fundamental to improve our understanding of $\mathrm{AOB}$ and AOA in the $\mathrm{N}$ cycle in the paddy soil.
\end{abstract}

Key words: Abundance, ammonia-oxidizing archaea (AOA), ammonia-oxidizing bacteria (AOB), Astragalus sinicus, community structure, Chinese milk vetch, soil chemical properties.

\section{INTRODUCTION}

Appropriate fertilizer application is an important management practice to improve soil fertility. In recent years, due to the rapid population growth and continuous decline in the amount of cultivated land area, the application rate of fertilizer keeps on rising in tropical and subtropical regions of China in order to obtain high crop production. However, the long-term inappropriate fertilization has caused many environmental problems, such as high acidity, low nutrients in cultivated land and unbalanced ecosystem (Chen et al., 2010). Recently, soil quality has gained much attention as a result of environmental issues related to soil degradation and production sustainability under different farming systems (Galantini and Rosell, 2006). Chinese milk vetch (Astragalus sinicus L., MV)

${ }^{1}$ Fujian Academy of Agricultural Sciences, Soil and Fertilizer Institute, Fuzhou, Fujian 350003, China.

*Corresponding author (xinjianlin@vip.tom.com).

Received: 30 December 2014.

Accepted: 28 April 2015.

doi:10.4067/S0718-58392015000500015 is considered as the most popular green manure in paddy field of South China, due to its high $\mathrm{N}$-fixing potential and better growth under wet paddy soil environment. Chinese milk vetch can partly replace $\mathrm{N}$ fertilizer and thus decrease application of $\mathrm{N}$ fertilizer.

Nitrification is a critical step in the $\mathrm{N}$ cycle and has significantly agricultural consequence for the $\mathrm{N}$ availability as a plant nutrient. Microbial oxidation of ammonia, the first and rate-limiting step of nitrification, can be performed by both ammonia-oxidizing bacteria (AOB) and ammonia-oxidizing archaea (AOA). Both groups have been detected in a wide variety of soil ecosystems (Chen et al., 2008; Di et al., 2009; Strauss et al., 2014). It is important to identify parameter that could impact the activities of AOB and AOA. Some previous studies have investigated the effects of fertilizer types, soil properties and land use on abundance and community structure of ammonia oxidizers in soils. Ai et al. (2013) reported that $\mathrm{N}$ fertilization greatly enhanced $\mathrm{AOB}$ abundance, while manure application increased AOA abundance. The community structure of $\mathrm{AOB}$ exhibited more obvious changes than that of AOA after 31-yr fertilizer field experiment. $\mathrm{Xu}$ et al. (2012) studied responses of AOB 
and AOA to different $\mathrm{N}$ fertilization rates. They reported that the AOB abundance was more abundant in the $\mathrm{N}$ fertilization treatments than the control, AOA abundance decreased with increasing $\mathrm{N}$ fertilization rates. Glaser et al. (2010) and Wu et al. (2011) suggested that bacteria rather than archaea dominate ammonia oxidation in nearneutral or alkaline soils and in acidic soils, AOA play a more important role in ammonia oxidization (Zhang et al., 2012). From above literature reviews, it demonstrated that $\mathrm{AOB}$ and $\mathrm{AOA}$ may prefer to different ecological environments.

In this study, the effects of organic and inorganic fertilizers on the abundance and community structures of $\mathrm{AOB}$ and AOA in field fertilization were investigated by using quantitative real-time polymerase chain reaction (qPCR) and denaturing gradient gel electrophoresis (DGGE) respectively.

\section{MATERIALS AND METHODS}

\section{Field design and sample collection}

A field fertilizer experiment was established in 2009 at Baisha Experimental Station (11904'10" E, 26¹3'31", N), Minhou County, Fuzhou, Fujian Province, China. This region has a subtropical monsoonal climate with an annual average temperature of $19.5^{\circ} \mathrm{C}$ and annual average precipitation of $1350 \mathrm{~mm}$. The experiment field is red soil, which is widespread in the South China. The soil is classified as typic Hapli-Stagnic Anthrosols (USDA). At the beginning of the experiment, the soil had a $\mathrm{pH}(1: 2.5)$ $5.26,31.41 \mathrm{~g} \mathrm{~kg}^{-1}$ soil organic matter (SOM), $1.23 \mathrm{~g} \mathrm{~kg}^{-1}$ total $\mathrm{N}$, and 13.51 and $85.48 \mathrm{mg} \mathrm{kg}^{-1}$ of available $\mathrm{P}$ and $\mathrm{K}$, respectively. Six treatments (three replicates each) were implemented in 18 plots $\left(15 \mathrm{~m}^{2}\right)$ under a $\mathrm{MV}$-rice (Oryza sativa L.) rotation; MV seeds were sown before the rice harvest and MV plants were ploughed into soil at full blooming stage in the following April. Treatments consisted of soil in absence of MV and chemical fertilizer (control, CK); 100\% chemical fertilizer N, P, and K (NPK); $18000 \mathrm{~kg} \mathrm{MV} \mathrm{ha}^{-1}$ plus $100 \%$ chemical fertilizer $\mathrm{N}, \mathrm{P}$, and K (NPKM1), $18000 \mathrm{~kg} \mathrm{MV} \mathrm{ha}^{-1}$ plus $60 \%$ chemical fertilizer N, P, and K (NPKM2), $18000 \mathrm{~kg} \mathrm{MV} \mathrm{ha}^{-1}$ alone (MV), $18000 \mathrm{~kg} \mathrm{MV} \mathrm{ha}^{-1}$ plus $40 \%$ chemical fertilizer $\mathrm{N}, \mathrm{P}$, and $\mathrm{K}$ and straw (NPKMS). For NPK treatment, fertilizer $\mathrm{N}, \mathrm{P}$, and $\mathrm{K}$ were applied in the form of urea (135 $\left.\mathrm{kg} \mathrm{N} \mathrm{ha}^{-1} \mathrm{yr}^{-1}\right)$, superphosphate $\left(54 \mathrm{~kg} \mathrm{P}_{2} \mathrm{O}_{5} \mathrm{ha}^{-1} \mathrm{yr}^{-1}\right)$, and potassium chloride (94.5 $\left.\mathrm{kg} \mathrm{K}_{2} \mathrm{O} \mathrm{ha}{ }^{-1} \mathrm{yr}^{-1}\right)$. Chinese MV (18 $000 \mathrm{~kg} \mathrm{ha}^{-1}$ ) contains $101 \mathrm{~g} \mathrm{~kg}^{-1} \mathrm{OM}, 3.7,1.1$, and 2.8 $\mathrm{g} \mathrm{kg}^{-1} \mathrm{~N}, \mathrm{P}$, and $\mathrm{K}$, respectively, and $86.2 \%$ water.

Surface soil samples were collected at 0-20 cm depth on October 2012 (after the harvest of rice). For each plot, five soil cores were taken and mixed to one composite sample. The fresh samples were placed immediately on ice and transported to the laboratory. Aliquots of the soil samples were then stored at $-80{ }^{\circ} \mathrm{C}$ refrigerator until molecular analysis, or $4{ }^{\circ} \mathrm{C}$ until chemical analysis.

\section{Soil chemical analysis}

Soil $\mathrm{pH}$ was measured with a soil to water ratio of 1:2.5. Soil organic matter was determined by the $\mathrm{K}_{2} \mathrm{Cr}_{2} \mathrm{O}_{7}$ oxidation method. Total $\mathrm{N}$ content (TN) was measured by Kjeldahl digestion analysis. Available $\mathrm{N}$ was determined by $\mathrm{NaOH}$ hydrolyzable method. The ammonium $\mathrm{N}$ $\left(\mathrm{NH}_{4}{ }^{+}-\mathrm{N}\right)$ was determined by extracting the soil with $2 \mathrm{M} \mathrm{KCl}$ solution and then detecting by indophenol blue colorimetric method. The nitrate $\mathrm{N}\left(\mathrm{NO}_{3}{ }^{-}-\mathrm{N}\right)$ was determined by dual wavelength spectrophotometry method (Huang et al., 2009).

\section{DNA extraction and real-time PCR}

Soil total DNA was extracted according to the method described by Zhou et al. (1996) with a modification. The weight of soil samples was decreased to $1 \mathrm{~g}$, the amount of DNA extraction buffer and proteinase $\mathrm{K}$ were also decreased to $1 / 5$ of the initial amount. Before the supernatants from the three cycles of extractions were extracted with an equal volume of chloroform-isoamyl alcohol, the supernatants were first extracted with phenolchloroform-isoamyl alcohol $(25: 24: 1)$. The pellet of crude nucleic acids was finally resuspended in $100 \mu \mathrm{L} \mathrm{TE}$ buffer. Successful DNA extraction was characterized by electrophoresis on $1 \%(\mathrm{w} / \mathrm{v})$ agarose gel.

The abundance of bacterial and archaeal amoA genes was determined by quantitative polymerase chain reaction (qPCR) using the primers amoA1-F/amoA2-R (Rotthauwe et al., 1997) and CrenamoA23f/CrenamoA616r (Tourna et al., 2008), respectively. Each reaction contained final $12.5 \mu \mathrm{L}$ Fast Start SYBR Green Master Mix (Takara, Dalian, China), $0.1 \mu \mathrm{L}$ of each primer $\left(5 \mathrm{pmol} \mu \mathrm{L}^{-1}\right), 0.2$ $\mu \mathrm{L}$ bovine serum albumin (20 $\left.\mathrm{mg} \mathrm{mL}^{-1}, \mathrm{BSA}\right)$, and $1 \mu \mathrm{L}$ 10 -fold diluted DNA template in a final volume of 25 $\mu \mathrm{L}$. Real-time PCR was conducted using thermal cycler (CFX96, Bio-Rad Laboratories, Hercules, California, USA) with the following conditions for ammoniaoxidizing bacteria (AOB): initial denaturation for $10 \mathrm{~min}$ at $95^{\circ} \mathrm{C}$, amplification for 38 cycles of $30 \mathrm{~s}$ at $95^{\circ} \mathrm{C}, 40 \mathrm{~s}$ at $57^{\circ} \mathrm{C}$ and $45 \mathrm{~s}$ at $72{ }^{\circ} \mathrm{C}$ and the following conditions for ammonia-oxidizing archaea (AOA): initial denaturation for $10 \mathrm{~min}$ at $95^{\circ} \mathrm{C}$, amplification for 38 cycles of 30 $\mathrm{s}$ at $95{ }^{\circ} \mathrm{C}, 45 \mathrm{~s}$ at $58{ }^{\circ} \mathrm{C}$ and $50 \mathrm{~s}$ at $72{ }^{\circ} \mathrm{C}$. Standard curve was generated by 10 -fold serial dilution of plasmid DNA amplified from soil using the qPCR primers. PCR efficiency and linearity $\left(\mathrm{r}^{2}\right)$ for $\mathrm{AOB}$ and $\mathrm{AOA}$ were $96.7 \%, 0.999$ and $100.4 \%, 0.999$, respectively.

\section{Denaturing gradient gel electrophoresis (DGGE) analysis}

To amplify AOB from soils for DGGE, nested PCR was performed (Zhang et al., 2010). The first PCR was conducted using the AOB-specific primer pair CTO189f and CTO654r which amplifies a 465-bp fragment (Kowalchuk et al., 1997). The PCR product was 50-fold diluted and then used as the template DNA for a second 
round of PCR using universal primers (F338GC and R518) (Muyzer et al., 1993). AOA amoA genes were amplified using primers CrenamoA23f/CrenamoA616r (Tourna et al., 2008). PCR mixtures consisted of $12.5 \mu \mathrm{L} 2 \times$ Taq mix (Tiangen, Beijing, China), $1 \mu \mathrm{L}$ of $5 \mathrm{pmol} \mu \mathrm{L}^{-1}$ of each primer, $20 \mathrm{ng}$ DNA template in a final volume of 25 $\mu \mathrm{L}$. PCR amplification was run on a T1 thermal cycler (Biometra, Goettingen, Germany) as previously described for AOB (Zhang et al., 2010) and AOA (Tourna et al., 2008) using the PCR conditions presented in Table 1. All PCR products were analyzed by electrophoresis on $1.5 \%$ (w/v) agarose to verify their size and quality.

DGGE was carried out using the DCode Universal Mutation Detection System (Bio-Rad) according to the manufacturer's instructions. A sample of $30 \mu \mathrm{L}$ of each PCR product was loaded onto an $8 \%(\mathrm{w} / \mathrm{v})$ polyacrylamide gel (acrylamide:bisacrylamide 37.5:1) with a denaturant gradient of $35 \%-60 \%$ for AOB and $20 \%-45 \%$ for AOA (100\% denaturant contains $7 \mathrm{M}$ urea and $40 \%$ deionized formamide). The electrophoresis was performed in $1 \times$ TAE buffer at $60{ }^{\circ} \mathrm{C}, 120 \mathrm{~V}$ for $6 \mathrm{~h}$. After staining with SYBR Green I (1:10 000) for $30 \mathrm{~min}$, gels were scanned with a BioSpectrum 410 imaging system (UVP, Upland, California, USA). Band numbers and relative intensity were analyzed using Quantity One analysis software (Bio-Rad).

\section{Cloning, sequencing, and phylogenetic analysis}

Dominant bands in the DGGE gels were excised, and each excised piece was washed twice with $1 \mathrm{~mL}$ of sterilized distilled water, and suspended into $30 \mu \mathrm{L}$ sterilized TE buffer ( $\mathrm{pH}$ 8.0) and kept overnight at $4{ }^{\circ} \mathrm{C}$. The DNA fragments were reamplified and PCR products were purified by gel extraction kit SK8132 (Sangon, Shanghai, China). The purified PCR products were ligated to the pMD-19T vector (Takara, Dalian, China) and inserted into $E$. coli $\mathrm{DH} 5 \alpha$ competent cells. Clones with the correct insert were sent to be sequenced. The nucleotide sequences were compared with those available in the National Center for Biotechnology Information (NCBI) GenBank database using the Basic Local Alignment Search Tool (BLAST) program (National Library of Medicine, NCBI, Bethesda, Maryland, USA). The nucleotides obtained from the NCBI GenBank database were aligned and a phylogenetic tree was constructed by the Neighbor-joining method implemented in MEGA version 5.0 (Tamura et al., 2011).

\section{Data analysis}

One-way ANOVA for bacterial and archaeal amoA gene copy number was performed using the software package SPSS for Windows version 16.0 (SPSS, Chicago, Illinois, USA). Comparison of mean values for different treatments was made using Duncan test. DGGE profiles were analyzed with Quantity One software (version 4.5, Bio-Rad) as described previously (Zhang et al., 2011). Redundancy analysis (RDA) was carried out using Canoco version 4.5 (Centre for Biometry, Wageningen, The Netherlands) to determine the multivariated relationships between community structures of AOB and AOA and soil properties.

\section{RESULTS}

\section{Effect of different fertilization regimes on soil chemical properties and rice yield}

The highest soil organic matter (SOM) content was in the MV treatment (Table 1), CK and NPK treatments had the lowest SOM. SOM only in the MV treatment was significantly higher than in the NPK treatment. SOM in treatments including NPKM1, NPKM2, and NPKMS were not different with the NPK treatment. CK and NPK treatments had the lowest total $\mathrm{N}$ and $\mathrm{TN}$ only in the MV and NPKMS treatments were significantly higher than in the NPK treatment. The highest available N was recorded in the NPKMS treatment and the lowest was recorded in the CK treatment. AN only in the NPKM1 and NPKMS treatments were significantly higher than in the NPK treatment. The NPKM1 treatment had the highest $\mathrm{NH}_{4}{ }^{+}-\mathrm{N}$ and there were no significant differences among other treatments. The highest content of $\mathrm{NO}_{3}$ -N was also observed in the NPKM1 treatment and the lowest was in the $\mathrm{CK}$ treatment. The $\mathrm{CK}$ treatment had the highest $\mathrm{pH}$ and fertilizer application could decrease soil $\mathrm{pH}$. Fertilization regimes had no significant effect on the soil $\mathrm{pH}$. From above results, it demonstrated that NPKMS fertilizer regime could maintain soil fertility although application of $40 \%$ chemical fertilizer.

Fertilization regimes had a significant effect on the rice yield (Figure 1). The NPKM1 treatment had the highest rice yield, around $9780 \mathrm{~kg} \mathrm{ha}^{-1}$. The NPKMS and NPK treatment had the second and third highest yield, 9340 and $9190 \mathrm{~kg} \mathrm{ha}^{-1}$ respectively. There was no significant

Table 1. Soil chemical properties under different fertilizer treatments.

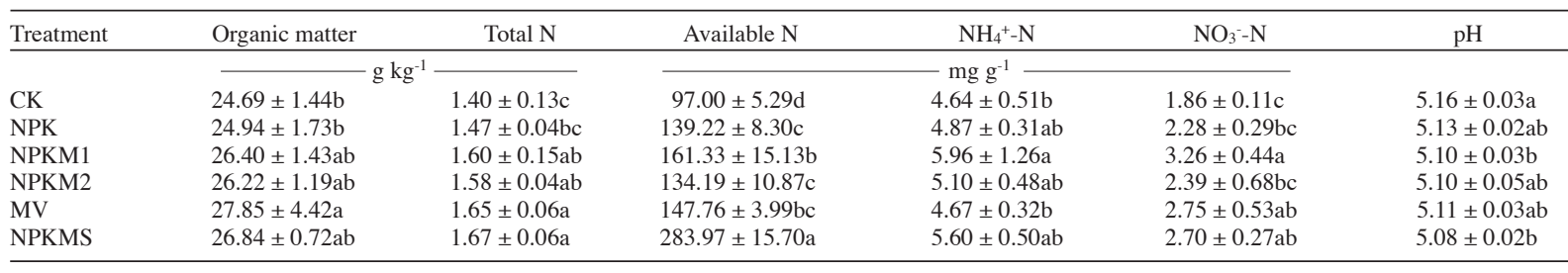

Data are means $\pm \mathrm{SD}, \mathrm{n}=3$. Values within the same column followed by the same letter do not differ at $P<0.05$. CK: Control without milk vetch (MV) and fertilizer; NPK: mineral NPK fertilizer; NPKM1: $18000 \mathrm{~kg} \mathrm{MV} \mathrm{ha}^{-1}$ plus 100\% NPK; NPKM2: $18000 \mathrm{~kg} \mathrm{MV} \mathrm{ha}^{-1}$ plus $60 \% \mathrm{NPK}^{2}$ MV: 18 000 kg MV ha-1; NPKMS: $18000 \mathrm{~kg} \mathrm{MV} \mathrm{ha}^{-1}$ plus $40 \%$ NPK and straw. 


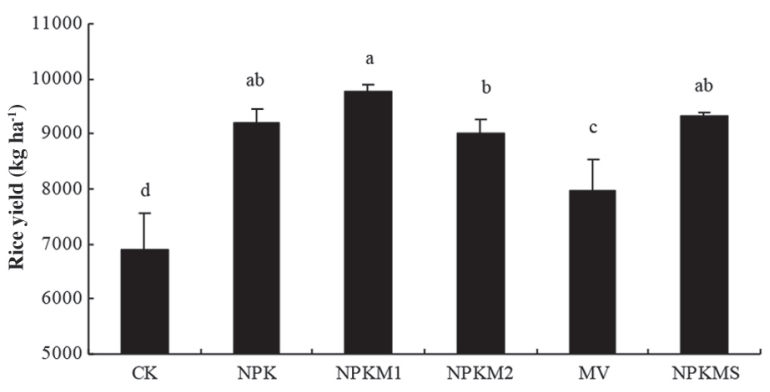

Vertical bars represent the standard deviations $(\mathrm{n}=3)$ and different letters indicate significant differences among fertilizer treatments $(P<0.05)$.

CK: Control without milk vetch (MV) and fertilizer; NPK: mineral NPK fertilizer; NPKM1: $18000 \mathrm{~kg} \mathrm{MV} \mathrm{ha}^{-1}$ plus 100\% NPK; NPKM2: 18000 kg MV ha-1 plus 60\% NPK; MV: $18000 \mathrm{~kg} \mathrm{MV} \mathrm{ha}^{-1}$; NPKMS: $18000 \mathrm{~kg}$ MV ha ${ }^{-1}$ plus $40 \%$ NPK and straw.

Figure 1. Rice yield under different fertilization treatments.

difference between NPKM1 and NPKMS treatments. The lowest yield was recorded in the CK treatment, around $6890 \mathrm{~kg} \mathrm{ha}^{-1}$. In view of the chemical properties and rice yield, the NPKMS treatment could be recommended as the best fertilization regime.

\section{Effect of different fertilization regimes on abundance of $\mathrm{AOB}$ and $\mathrm{AOA}$}

Mean AOB abundance ranged from $5.22 \times 10^{6}$ to 1.76 $\times 10^{7}$ copies $\mathrm{g}^{-1}$ dry soil under different treatments (Figure 2). The highest AOB population size was found in the MV treatment, followed by the NPKM1, NPKMS, CK, NPKM2, and NPK treatments. The lowest AOB population size appeared in the NPK treatment, with the MV treatment 3.36 times higher than the NPK treatment. The population sizes of AOB in MV treatment and MV plus mineral fertilizer treatments with the exception of the NPKM2 were significantly higher than in the NPK treatment. However, mean AOA abundance ranged from $3.21 \times 10^{7}$ to $1.19 \times 10^{8}$ copies $\mathrm{g}^{-1}$ dry soil under different treatments. The population sizes of AOA in all fertilizer treatments were higher than that in the control soil. The abundance of AOA in NPKM1 and NPKMS treatments were significantly higher than in the NPK treatment.

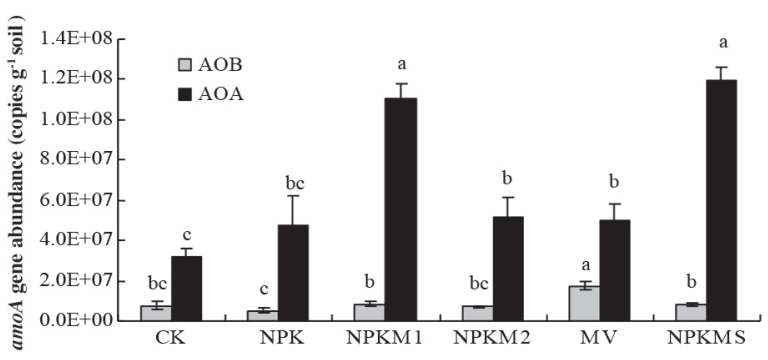

Vertical bars represent the standard deviations $(\mathrm{n}=3)$ and different letters indicate significant differences among fertilizer treatments $(P<0.05)$.

CK: Control without milk vetch (MV) and fertilizer; NPK: mineral NPK fertilizer; NPKM1: $18000 \mathrm{~kg} \mathrm{MV} \mathrm{ha}^{-1}$ plus 100\% NPK; NPKM2: 18000 kg MV ha ${ }^{-1}$ plus 60\% NPK; MV: $18000 \mathrm{~kg} \mathrm{MV} \mathrm{ha}^{-1}$; NPKMS: $18000 \mathrm{~kg}$ MV ha ${ }^{-1}$ plus $40 \%$ NPK and straw.

Figure 2. Abundance of soil ammonia-oxidizing bacteria (AOB) and ammonia-oxidizing archaea (AOA) under different fertilization.
Correlation analysis confirmed that the $\mathrm{AOB}$ population size was significantly positively related to SOM and total $\mathrm{N}$ contents at $P<0.01$ and $P<0.05$, respectively (Table 2). Available $\mathrm{N}, \mathrm{NH}_{4}{ }^{+}-\mathrm{N}, \mathrm{NO}_{3}{ }^{-}-\mathrm{N}$, and rice yield were significantly positively related to AOA abundance $(P<$ 0.01 ), and there was a significantly positive correlation between total $\mathrm{N}$ and AOA abundance $(P<0.05)$. Soil $\mathrm{pH}$ was negatively related to AOA abundance $(P<0.05)$.

\section{Effect of different fertilization regimes on community} structure of $\mathrm{AOB}$ and $\mathrm{AOA}$

The community structures of $\mathrm{AOB}$ and AOA in soils were characterized by DGGE. All fertilizer treatments resulted in increased numbers of $\mathrm{AOB}$ bands in the DGGE profiles (Figure 3a). Specifically, band 20 was only detected in the NPK treatment. Bands 18, 19, and 21 were added in comparison with the $\mathrm{CK}$ treatment. This result was confirmed by Cluster analysis, which showed that fertilizer treatments were clearly separated from the CK treatment (Figure 4a). These findings indicate that the fertilization regimes might play a major role in shaping the soil AOB community structure.

The predominant bands in the AOB DGGE profile were sequenced for phylogenetic analysis (Figure 5). The AOB DGGE profile corresponding to all treatments was dominated by bands $1,7-14$, and 17 , which were affiliated with the Nitrosospira. Band 15 affiliated with Nitromonas was also found in all soil samples. Bands 18, 19, and 21 detected in the fertilizer treatments were all affiliated with Nitromonas.

In contrast to the AOB community, the DGGE profiles of AOA remained largely unchanged for most treatments (Figure 3b). Cluster analysis revealed that all treatments were not separated from each other (Figure 4b). Phylogenetic analysis showed that all sequences of these bands were very similar to amoA gene clone from soil and sediment lineage, especially from acidic paddy soil (Figure 6).

The Shannon index of AOB in fertilizer treatments were significantly higher than those in the CK treatment (Table 3). Among fertilization treatments, NPKM1 treatment had the highest Shannon index and NPKM2 treatment had the lowest Shannon index. There were no significant differences in other fertilizer treatments. The NPK and MV treatments had the highest richness index, and the lowest richness index was observed in the CK treatment. In contrast, the NPK treatment had the lowest Shannon and richness indices of AOA. Fertilization regimes had no significant effect on the diversity of AOA compared to the CK treatment.

Table 2. Correlations of soil properties, yield and abundance of ammonia-oxidizing bacteria (AOB) and ammonia-oxidizing archaea (AOA).

\begin{tabular}{llllllll}
\hline & $\begin{array}{c}\text { Organic } \\
\text { matter }\end{array}$ & $\begin{array}{c}\text { Total } \\
\mathrm{N}\end{array}$ & $\begin{array}{c}\text { Available } \\
\mathrm{N}\end{array}$ & $\mathrm{NH}_{4}{ }^{+}-\mathrm{N}$ & $\mathrm{NO}^{-}{ }^{-} \mathrm{N}$ & $\mathrm{pH}$ & Yield \\
\hline $\mathrm{AOB}$ & $0.627^{* *}$ & $0.53^{*}$ & 0.024 & -0.233 & 0.3 & -0.059 & -0.266 \\
$\mathrm{AOA}$ & 0.308 & $0.511^{*}$ & $0.785^{* * *}$ & $0.625^{* *}$ & $0.637^{* *}$ & $-0.577^{*}$ & $0.703^{* * *}$ \\
\hline
\end{tabular}

, ** Significant at the 0.05 and 0.01 probability level, respectively. 

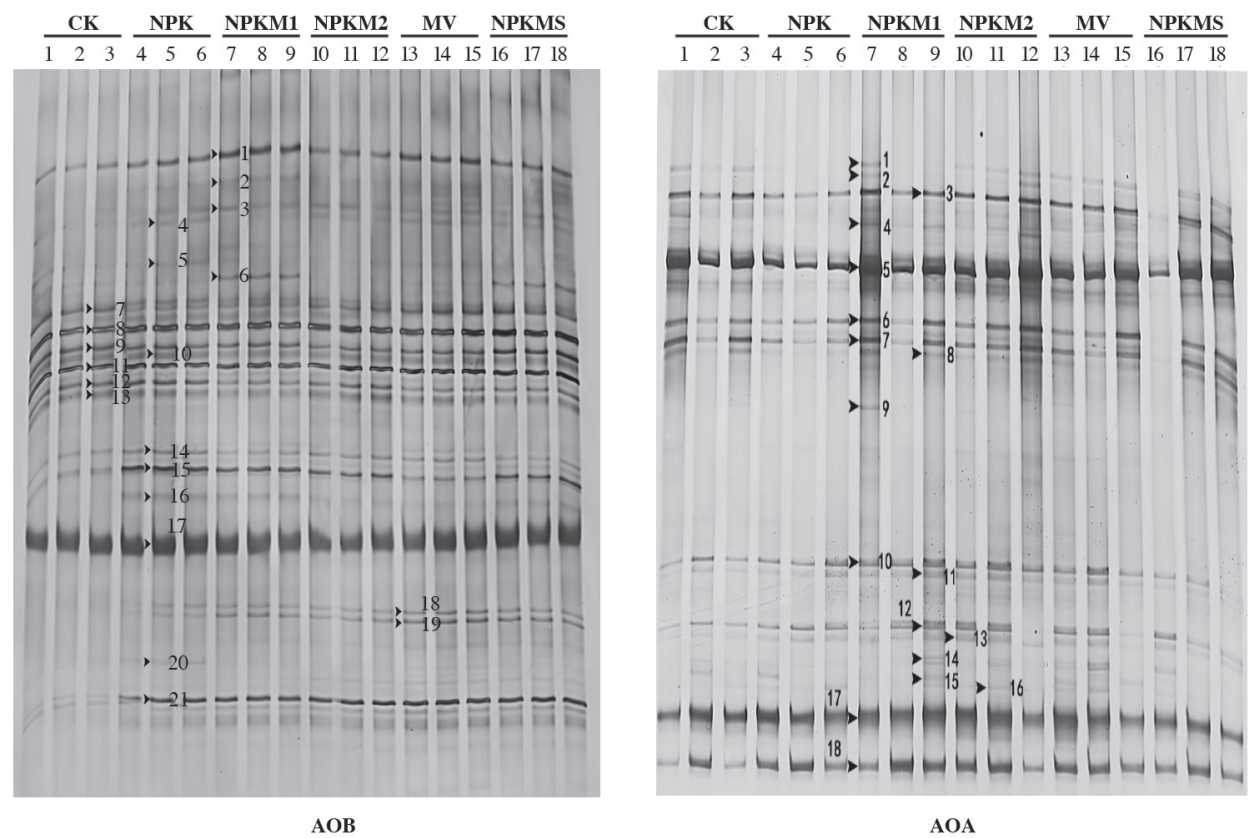

CK: Control without milk vetch (MV) and fertilizer; NPK: mineral NPK fertilizer; NPKM1: $18000 \mathrm{~kg} \mathrm{MV} \mathrm{ha-1} \mathrm{plus} 100 \%$ NPK; NPKM2: $18000 \mathrm{~kg}$ MV ha ${ }^{-1}$ plus 60\% NPK; MV: $18000 \mathrm{~kg} \mathrm{MV} \mathrm{ha}^{-1}$; NPKMS: $18000 \mathrm{~kg} \mathrm{MV} \mathrm{ha-1}^{-1}$ plus 40\% NPK and straw.

Figure 3. DGGE analysis of soil ammonia-oxidizing bacteria (AOB) and ammonia-oxidizing archaea (AOA) under different fertilization.

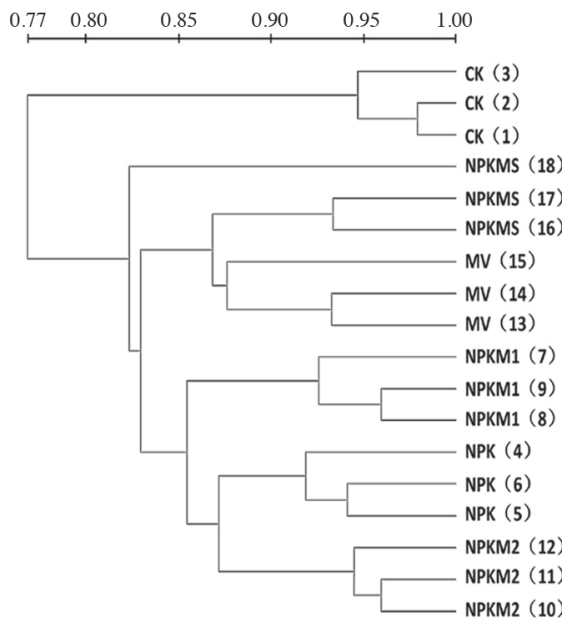

AOB

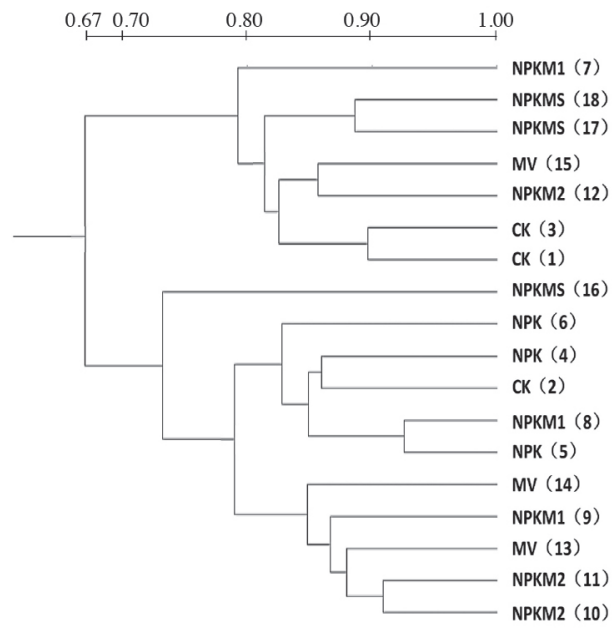

AOA

CK: Control without milk vetch (MV) and fertilizer; NPK: mineral NPK fertilizer; NPKM1: $18000 \mathrm{~kg} \mathrm{MV} \mathrm{ha}^{-1}$ plus $100 \%$ NPK; NPKM2: $18000 \mathrm{~kg}$ MV ha ${ }^{-1}$ plus 60\% NPK; MV: $18000 \mathrm{~kg} \mathrm{MV} \mathrm{ha}^{-1}$ alone; NPKMS: $18000 \mathrm{~kg} \mathrm{MV} \mathrm{ha}^{-1}$ plus 40\% NPK and straw.

Figure 4. Similarity dendrograms (UPGMA) of ammonia-oxidizing bacteria (AOB) and ammonia-oxidizing archaea (AOA) banding patterns calculated from DGGE patterns.

Correlations of soil properties with community structures of ammonia-oxidizing bacteria and archaea RDA was performed to determine the correlations of soil properties with community structures of $\mathrm{AOB}$ and $\mathrm{AOA}$. The first and second axes explained $27.0 \%$ and $8.1 \%$, respectively, of the variance in $\mathrm{AOB}$ community structure (Figure 7a). Available N $(F=3.850, r=0.194, P=0.004)$, soil $\mathrm{pH}(F=3.191, r=0.166, P=0.002)$ and $\mathrm{NH}_{4}{ }^{+}-\mathrm{N}$ content $(F=2.628, r=0.141, P=0.044)$ significantly correlated with AOB structure. The rest of the investigated soil properties did not correlate with $\mathrm{AOB}$ community structure $(P>0.05)$.

The first and second axes explained $12.9 \%$ and $8.5 \%$, respectively, of the variance in AOA community structure (Figure 7b). However, all soil properties did not significantly correlate with community structure of AOA $(P>0.05)$. 


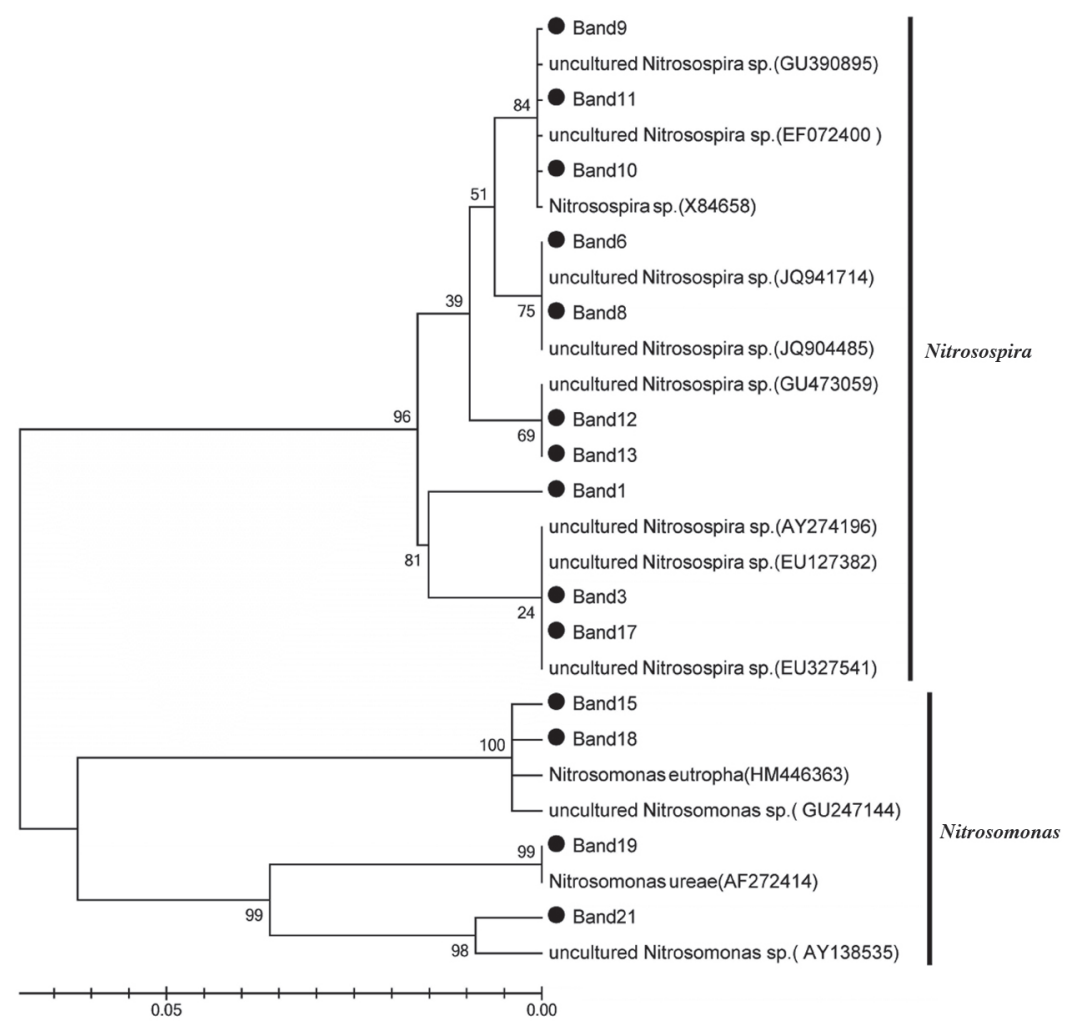

Figure 5. Neighbor-joining tree of soil ammonia-oxidizing bacteria (AOB) retrieved from the DGGE bands and from the NCBI GenBank database.

\section{DISCUSSION}

Bacterial amoA gene copy numbers ranged from $5.22 \times 10^{6}$ to $1.76 \times 10^{7}$ per gram of dry soil. Compared with $\mathrm{AOB}$, the archaeal amoA copy numbers were more abundant, ranging from $3.21 \times 10^{7}$ to $1.19 \times 10^{8}$ per gram of dry soil in our study. The result was consistent with some previous studies that also demonstrated AOA were more abundant than AOB in agricultural soils (He et al., 2007; Mincer et al., 2007; Ying et al., 2010). The abundance of $\mathrm{AOB}$ and $\mathrm{AOA}$ were higher in the MV or MV plus mineral fertilizer treatments than in the NPK treatment. Higher level of AOB and AOA in the MV or MV plus mineral fertilizer treatments can be associated with the highest $\mathrm{C}$ bioavailability, but this could not explain the abundance of AOB in the CK treatment. Furthermore, there was no significant difference in the population size of $\mathrm{AOB}$ among fertilizer treatments with the exception of the MV treatment and CK. This was inconsistent with previous studies that showed the population size of AOB increased significantly after fertilization (Wu et al., 2011; Ai et al., 2013; Strauss et al., 2014). Compared with AOB, the population size of AOA responded to fertilizers in a different manner (Figure 2). The abundance of AOA was significantly higher than $\mathrm{CK}$ treatment after fertilizer application, however, there was no significant difference in the population size of AOA between the NPK and
CK treatments. These results were consistent with the study conducted by Ai et al. (2013), which showed that fertilizer application could increase the AOA abundance in the rhizosphere and bulk soil during maize season. Positive correlations between AOA abundance and total $\mathrm{N}$, available $\mathrm{N}, \mathrm{NH}_{4}{ }^{+}-\mathrm{N}$, and $\mathrm{NO}_{3}{ }^{-}-\mathrm{N}$ were observed in the present study (Table 2). These results indicated that $\mathrm{N}$ condition may be a key factor affecting the population size of AOA in the acidic soil. Positive correlations between AOA abundance and organic $\mathrm{C}$ and total $\mathrm{N}$ observed by Ai et al. (2013) support the idea that AOA have alternative growth strategies for mixotrophic and heterotrophic growth (Walker et al., 2010). However, there was no correlation between AOA abundance and OM which support the idea that AOA may have autotrophic growth strategies. In our study, soil $\mathrm{pH}$ was negatively related to AOA abundance, this result was also observed by Nicol et al. (2008).

DGGE analysis revealed that the community structure of AOB was highly sensitive to fertilization regimes. Cluster analysis demonstrated that fertilization treatments were clearly separated from CK treatment (Figure 4a). Diversity indices analysis also demonstrated that application of fertilizer could increase the community diversity of AOB (Table 3). Chu et al. (2007) also reported that the AOB community structure was more diverse in $\mathrm{N}$-fertilized treatments than in the control. Many previous 


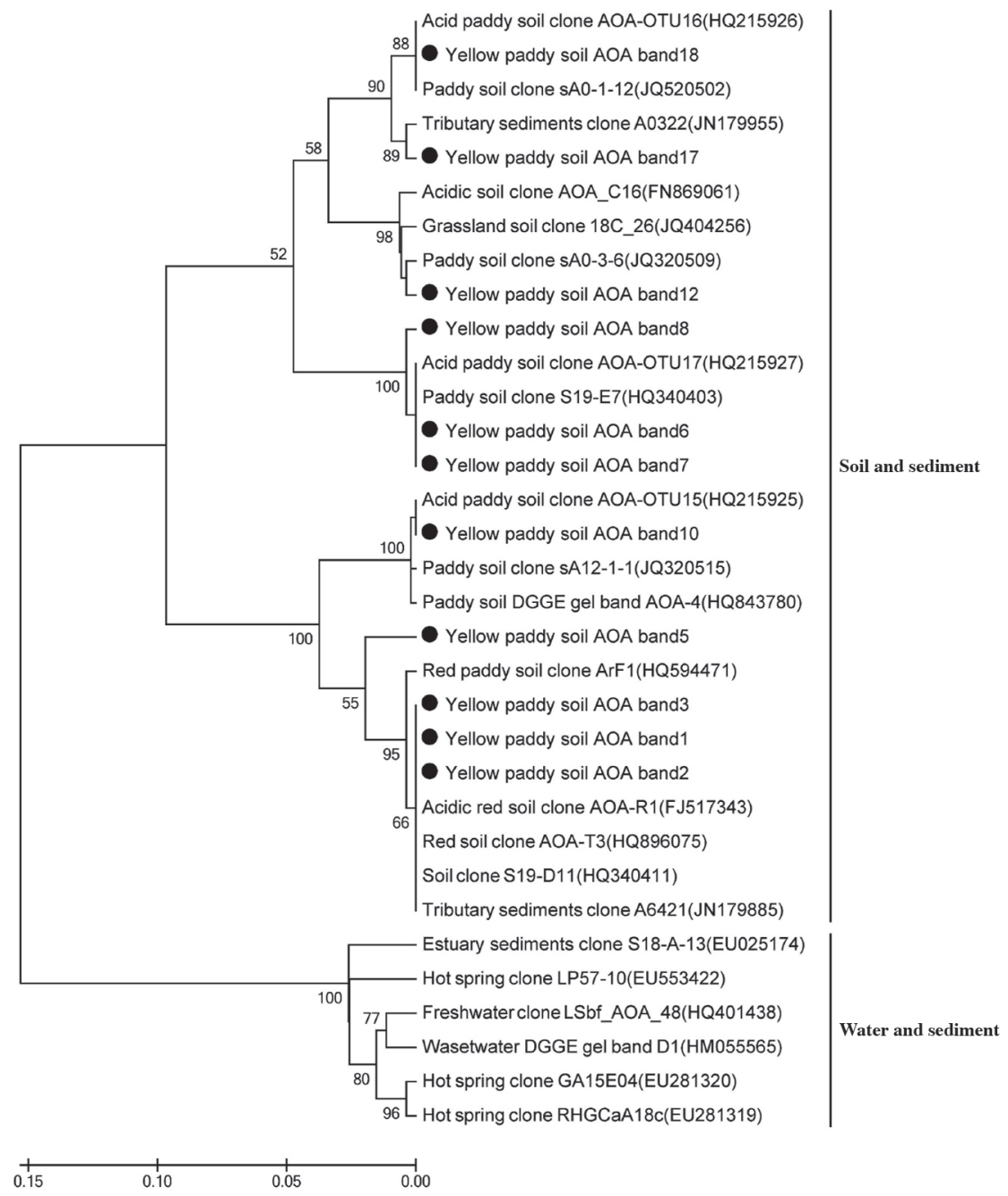

Figure 6. Neighbor-joining tree of soil ammonia-oxidizing archaea (AOA) retrieved from the DGGE bands and from the NCBI GenBank database.

studies have demonstrated that the predominance of Nitrosospira over Nitrosomonas in AOB community in terrestrial ecosystems (Innerebner et al., 2006; He et al., 2007; Ai et al., 2013). This study also revealed that the sequences related to Nitrosospira predominant in the

Table 3. Diversity indices of soil ammonia-oxidizing bacteria (AOB) and ammonia-oxidizing archaea (AOA).

\begin{tabular}{llllll}
\hline & \multicolumn{2}{c}{ AOB } & & \multicolumn{2}{c}{ AOA } \\
\cline { 2 - 3 } \cline { 5 - 6 } Treatment & Shannon $(H)$ & Richness $(S)$ & & Shannon $(H)$ & Richness $(S)$ \\
\hline CK & $2.42 \pm 0.02 \mathrm{~d}$ & $13.00 \pm 0.00 \mathrm{~d}$ & & $2.54 \pm 0.00 \mathrm{abc}$ & $15.33 \pm 0.58 \mathrm{ab}$ \\
NPK & $2.87 \pm 0.02 \mathrm{bc}$ & $20.67 \pm 0.58 \mathrm{a}$ & & $2.40 \pm 0.10 \mathrm{c}$ & $13.00 \pm 1.00 \mathrm{~b}$ \\
NPKM1 & $2.96 \pm 0.02 \mathrm{a}$ & $20.00 \pm 0.00 \mathrm{~b}$ & & $2.69 \pm 0.30 \mathrm{ab}$ & $17.67 \pm 4.04 \mathrm{a}$ \\
NPKM2 & $2.83 \pm 0.01 \mathrm{c}$ & $19.00 \pm 0.00 \mathrm{c}$ & & $2.80 \pm 0.05 \mathrm{a}$ & $19.00 \pm 1.00 \mathrm{a}$ \\
MV & $2.88 \pm 0.04 \mathrm{~b}$ & $20.67 \pm 0.58 \mathrm{a}$ & & $2.71 \pm 0.03 \mathrm{a}$ & $17.67 \pm 1.15 \mathrm{a}$ \\
NPKMS & $2.87 \pm 0.08 \mathrm{bc}$ & $20.00 \pm 0.00 \mathrm{~b}$ & & $2.41 \pm 0.18 \mathrm{bc}$ & $13.00 \pm 2.00 \mathrm{~b}$ \\
\hline
\end{tabular}

Data are means $\pm S D, n=3$. Values within the same column followed by the same letter do not differ at $\mathrm{P}<0.05$.

CK: Control without milk vetch (MV) and fertilizer; NPK: mineral NPK fertilizer; NPKM1: $18000 \mathrm{~kg} \mathrm{MV} \mathrm{ha}^{-1}$ plus 100\% NPK; NPKM2: $18000 \mathrm{~kg}$ MV ha-1 plus 60\% NPK; MV: $18000 \mathrm{~kg} \mathrm{MV} \mathrm{ha}^{-1}$; NPKMS: $18000 \mathrm{~kg}$ MV ha $^{-1}$ plus $40 \%$ NPK and straw. paddy soil. These findings are inconsistent with the results of some previous studies in which only Nitrosospira and not Nitrosomonas spp. were detected in soil (Chu et al., 2007; Wu et al., 2011). It is likely caused by the differences in soil type which is the primary determinants of the composition of the bacterial communities in arable soils (Girvan et al., 2003). In this study, the differences in the AOB community structure among treatments were correlated with the soil $\mathrm{pH}$ (Figure 7a), indicating that $\mathrm{pH}$ plays an important role in shaping the $\mathrm{AOB}$ community structure. Unlike AOB, we observed that community structure of AOA exhibited no obvious change which is consistent by Shen et al. (2011) and Wang et al. (2009). Fan et al. (2011) also reported that the community structure of AOA in soil exhibited little variation among fertilization treatments. Cluster analysis showed that the CK treatment could not be clearly separated from the fertilized treatments (Figure 4b). Diversity analysis demonstrated that there 
were no significant differences in Shannon and richness indices between fertilized treatments and the control (Table 3). Above results demonstrated that AOB and AOA responded to fertilizer regimes in a different way.
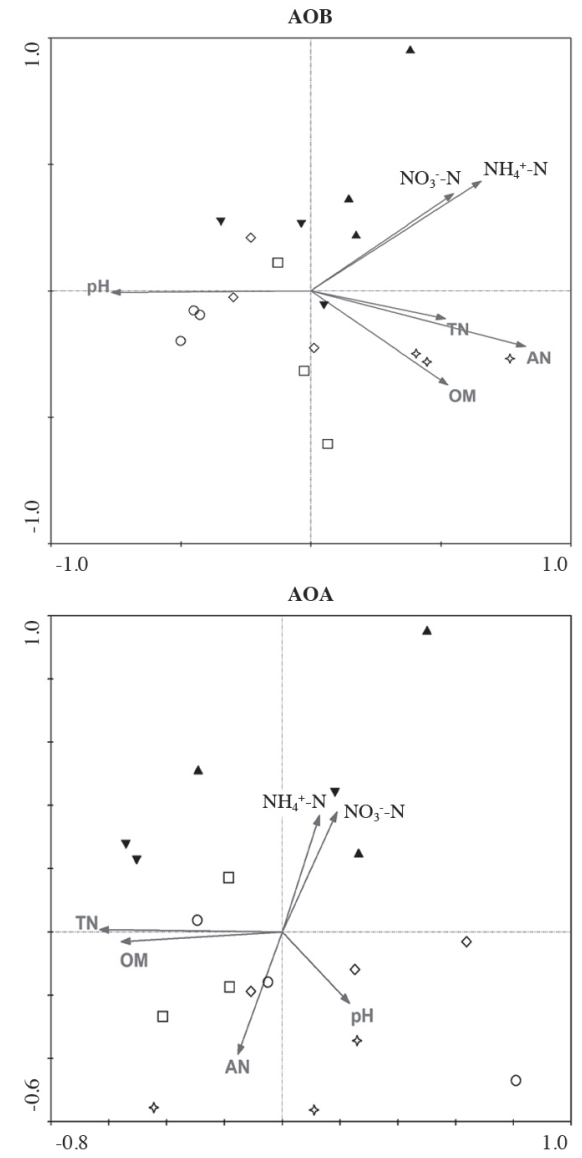

OCK: Control without milk vetch (MV) and fertilizer; $\diamond$ NPK: mineral NPK fertilizer; $\boldsymbol{\Delta}$ NPKM1: $18000 \mathrm{~kg}$ MV ha $\mathrm{h}^{-1}$ plus $100 \%$ NPK; V NPKM2: $18000 \mathrm{~kg} \mathrm{MV} \mathrm{ha}^{-1}$ plus 60\% NPK; $\square \mathrm{MV}$ : $18000 \mathrm{~kg} \mathrm{MV} \mathrm{ha}^{-1}$ alone; $\$$ NPKMS: $18000 \mathrm{~kg} \mathrm{MV} \mathrm{ha}^{-1}$ plus $40 \%$ NPK and straw.

Figure 7. Correlations of soil properties with community structure of ammonia-oxidizing bacteria $(\mathrm{AOB})$ and ammonia-oxidizing archaea (AOA) as determined by redundancy analysis (RDA).

\section{CONCLUSIONS}

This study demonstrated that fertilizer regimes had impacts on the soil properties, the activities and community structures of ammonia-oxidizing bacteria (AOB) and ammonia-oxidizing archaea (AOA). The NPKMS treatment was recommended as a better fertilizer practice with higher soil fertility, rice yield and application of less chemical fertilizer. Chemical fertilizer plus green manure increased the population size of AOA significantly, whereas fertilization regimes had little effects on AOB abundance. Fertilizer application had little impact on the community structure of AOA. In contrast, the community structure of $\mathrm{AOB}$ was highly sensitive to fertilization regimes and the application of fertilizer could increase the diversity of AOB. However, the mechanisms which drive the response of $\mathrm{AOB}$ and $\mathrm{AOA}$ to different fertilization regimes are still unknown and need further study.

\section{ACKNOWLEDGEMENTS}

This research was financially supported by the Special Fund for Agroscientific Research in the Public Interest (201103005), China.

\section{LITERATURE CITED}

Ai, C., G.Q. Liang, J.W. Sun, X.B. Wang, P. He, and W. Zhou. 2013. Different roles of rhizosphere effect and long-term fertilization in the activity and community structure of ammonia oxidizers in a calcareous fluvo-aquic soil. Soil Biology and Biochemistry 57:30-42.

Chen, W.C., K.R. Wang, and X.L. Xie. 2010. Effects of distributions of carbon and nitrogen in a reddish paddy soil under long-term different fertilization treatments. Chinese Journal of Soil Sciences 40:523-528.

Chen, X.P., Y.G. Zhu, Y. Xia, J.P. Shen, and J.Z. He. 2008. Ammoniaoxidizing archaea: important players in paddy rhizosphere soil? Environmental Microbiology 10:1978-1987.

Chu, H.Y., T. Fujii, S. Morimoto, X.G. Lin, K. Yagi, J.L. Hu, et al. 2007. Community structure of ammonia-oxidizing bacteria under long-term application of mineral fertilizer and organic manure in a sandy loam soil. Applied and Environmental Microbiology 73:485-491.

Di, H.J., K.C. Cameron, J.P. Shen, C.S. Winefield, M. O'Callaghan, S. Bowatte, et al. 2009. Nitrification driven by bacteria and not archaea in nitrogen-rich grassland soils. Nature Geoscience 2:621-624.

Fan, F.L., Q.B. Yang, Z.J. Li, D. Wei, X.A. Cui, and Y.C. Liang. 2011. Impacts of organic and inorganic fertilizers on nitrification in a cold climate soil are linked to the bacterial ammonia oxidizer community. Microbial Ecology 62:982-990.

Galantini, J., and R. Rosell. 2006. Long-term fertilization effects on soil organic matter quality and dynamics under different production systems in semiarid Pampean soils. Soil and Tillage Research 87:72-79.

Girvan, M.S., J. Bullimore, J.N. Pretty, A.M. Osborn, and A.S. Ball. 2003. Soil type is the primary determinant of the composition of the total and active bacterial communities in arable soils. Applied and Environmental Microbiology 69:1800-1809.

Glaser, K., E. Hackl, E. Inselsbacher, J. Strauss, W. Wanek, S. Zechmeister-Boltenstern, et al. 2010. Dynamics of ammoniaoxidizing communities in barley-planted bulk soil and rhizosphere following nitrate and ammonium fertilizer amendment. FEMS Microbiological Ecology 74:575-591.

He, J.Z., J.P. Shen, L.M. Zhang, Y.G. Zhu, Y.M. Zheng, M.G. Xu, et al. 2007. Quantitative analyses of the abundance and composition of ammonia-oxidizing bacteria and ammonia-oxidizing archaea of a Chinese upland red soil under long-term fertilization practices. Environmental Microbiology 9:2364-2374.

Huang, Y.F., Y.L. Ye, and S.Q. Yang. 2009. Feasibility of $\mathrm{NO}_{3}{ }^{-} \mathrm{N}$ determination by dual wavelength spectrophotometric method. Chinese Agricultural Science Bulletin 25(2):43-45.

Innerebner, G., B. Knapp, T. Vasara, M. Romantschuk, and H. Insam. 2006. Traceability of ammonia-oxidizing bacteria in composttreated soils. Soil Biology and Biochemistry 38:1092-1100.

Kowalchuk, G.A., J.R. Stephen, W. De Boer, J.I. Prosser, T.M. Embley, and J.W. Woldendorp. 1997. Analysis of ammoniaoxidizing bacteria of the beta subdivision of the class Proteobacteria in coastal sand dunes by denaturing gradient electrophoresis and sequencing of PCR-amplified 16S ribosomal DNA fragments. Applied and Environmental Microbiology 63:1489-1497. 
Mincer, T.J., M.J. Church, L.T. Taylor, C. Preston, D.M. Karl, and E.F. DeLong. 2007. Quantitative distribution of presumptive archaeal and bacterial nitrifiers in Monterey Bay and the North Pacific Subtrophical Gyre. Environmental Microbiology 9:1162-1175.

Muyzer, G., E.C. de Waal, and A.G. Uitterlinden. 1993. Profiling of complex microbial populations by denaturing gradient gel electrophoresis analysis of polymerase chain reaction-amplified genes coding for $16 \mathrm{~S}$ rRNA. Applied and Environmental Microbiology 59:695-700.

Nicol, G.W., S. Leininger, C. Schleper, and J.I. Prosser. 2008. The influence of soil $\mathrm{pH}$ on the diversity, abundance and transcriptional activity of ammonia oxidizing archaea and bacteria. Environmental Microbiology 10:2966-2978.

Rotthauwe, J.H., K.P. Witzel, and W. Liesack. 1997. The ammonia monooxygenase structural gene $a m o A$ as a functional marker: molecular fine-scale analysis of natural ammonia-oxidizing populations. Applied and Environmental Microbiology 63:4704-4712.

Shen, X.Y., L.M. Zhang, J.P. Shen, L.H. Li, C.L. Yuan, and J.Z. He. 2011. Nitrogen loading levels affect abundance and composition of soil ammonia oxidizing prokaryotes in semiarid temperate grassland. Journal of Soils and Sediment 11:1243-1252.

Strauss, S.L., C.L. Reardon, and M. Mazzola. 2014. The response of ammonia-oxidizer activity and community structure to fertilizer amendment of orchard soils. Soil Biology and Biochemistry 68:410-418.

Tamura, K., D. Peterson, N. Peterson, G. Stecher, M. Nei, and S. Kumar. 2011. MEGA5: molecular evolutionary genetics analysis using maximum likelihood, evolutionary distance, and maximum parsimony methods. Molecular Biology and Evolution 28:2731-2739.

Tourna, M., T.E. Freitag, G.W. Nicol, and J.I. Prosser. 2008. Growth, activity and temperature responses of ammonia-oxidizing archaea and bacteria in soil microcosms. Environmental Microbiology 10:1357-1364.
Walker, C.B., J.R. de la Torre, M.G. Klotz, H. Urakawa, N. Pinel, D.J. Arp, et al. 2010. Nitrosopumilus maritimus genome reveals unique mechanisms for nitrification and autotrophy in globally distributed marine crenarchaea. Proceedings of the National Academy of Sciences of the United States of America 107:8818-8823.

Wang, Y.A., X.B. Ke, L.Q. Wu, and Y.H. Lu. 2009. Community composition of ammonia-oxidizing bacteria and archaea in rice field soil as affected by nitrogen fertilization. Systematic and Applied Microbiology 32:27-36.

Wu, Y., L. Lu, B. Wang, X. Lin, J. Zhu, Z. Cai, et al. 2011. Longterm field fertilization significantly alters community structure of ammonia-oxidizing bacteria rather than archaea in a paddy soil. Soil Science Society of America Journal 75:1431-1439.

Xu, Y.G., W.T. Yu, Q. Ma, and H. Zhou. 2012. Responses of bacterial and archaeal ammonia oxidizers of an acidic luvisols soil to different nitrogen fertilization rates after 9 years. Biology and Fertility of Soils 48(7):827-837.

Ying, J.Y., L.M. Zhang, and J.Z. He. 2010. Putative ammoniaoxidizing bacteria and archaea in an acidic red soil with different land utilization patterns. Environmental Microbiology Reports 2:304-312.

Zhang, L.M., H.W. Hu, J.P. Shen, and J.Z. He. 2012. Ammoniaoxidizing archaea have more important role than ammoniaoxidizing bacteria in ammonia oxidation of strongly acidic soils. The ISME Journal 6:1032-1045.

Zhang, B., B.S. Sun, M. Ji, H.N. Liu, and X.H. Liu. 2010. Quantification and comparison of ammonia-oxidizing bacterial communities in MBRs treating various types of wastewater. Bioresource Technology 101:3054-3059.

Zhang, J.C., G.M. Zeng, Y.N. Chen, M. Yu, Z. Yu, H. Li, et al. 2011. Effects of physico-chemical parameters on the bacterial and fungal communities during agricultural waste composting. Bioresource Technology 102:2950-2956.

Zhou, J., M.A. Bruns, and J.M. Tiedje. 1996. DNA recovery from soils of diverse composition. Applied and Environmental Microbiology 62:316-322. 